\title{
A DEMONOLOGIZAÇÃO DO NEGRO EM DEL AMOR Y OTROS DEMONIOS
}

\author{
Cinthia da Silva Belonia ${ }^{1}$
}

\begin{abstract}
RESUMO: Neste artigo aborda-se, no romance Del amor y otros demonios, de Gabriel García Márquez, publicado em 1994, a demonologização pela Igreja Católica do escravo negro e de brancos transgressores do discurso religioso como forma de dominação colonialista. Segundo se registra no prólogo do romance, em 26 de outubro de 1949, o autor/narrador, jornalista em busca de notícias, foi assistir a demolição das criptas do Convento de Santa Clara. A destruição do Convento para a construção de um hotel de luxo, não é, entretanto, o que chama a atenção do jornalista, mas a ossatura de uma menina de aproximadamente doze anos, com uma enorme cabeleira cor de cobre agarrada ao crânio, medindo 22 metros e 11 centímetros, encontrada nos escombros do Convento. Em sua lápide, havia apenas um nome sem sobrenomes: Sierva María de Todos los Ángeles. No romance, a personagem é acusada pela Igreja de ser vítima de possessão demoníaca. Essa acusação se deve não só ao comportamento agressivo da personagem, após ter sido atacada e mordida por um cão raivoso, mas também aos costumes de Sierva María, identificados com a cultura negra, uma vez que a menina branca era criada na senzala dos escravos de seus pais.
\end{abstract}

PALAVRAS-CHAVE: demonologização; Igreja; negro; intolerância; Gabriel García Márquez.

ABSTRACT: This article discusses how the demonization by the Catholic Church of the black slave as well as of the white offenders of religion works as a form of colonial domination in Gabriel Garcia Marquez' Del amor y otros demonios, published in 1994. As it is said in the prologue of the novel, on 26 October 1949 the author/narrator, a journalist seeking news, went to watch the demolition of the crypts of Santa Clara's Convent. The destruction of the convent leading to the building of a luxury hotel is not however what draws the journalist's attention, but rather the bones of a girl of about twelve, with a huge copper-colored hair of 22 meters and 11 centimeters clinging to her skull, found in the ruins of the Convent. On her tombstone there was only one a name without surnames: Sierva María de Todos los Ángeles. In the novel the character is accused by the Church of being a victim of demonic possession. This accusation is not only due to the aggressive behavior of the character after being attacked and bitten by a rabid dog, but also the intolerance towards Sierva Maria's customs linked to black culture, once she was a white girl who was raised in the slave house among her father's slaves.

KEYWORDS: demonization; Church; black; intolerance; Gabriel García Márquez.

\section{INTRODUÇÃO}

No romance Del amor y otros demonios (1994), de Gabriel García Márquez, a personagem Sierva María de Todos los Ángeles será acusada pela Igreja de ser vítima de possessão demoníaca. Sierva María é uma personagem complexa. Trata-se de uma menina que possui um comportamento identificado com o ethos negro-africano, apesar da pele branca, do título de marquesa, da posição social considerável em sua cidade e de um nome de batismo

\footnotetext{
${ }^{1}$ Doutoranda em Literatura Comparada na Universidade Federal Fluminense. Mestre em Literatura Hispanoamericana pela Universidade Federal Fluminense. Graduada em Letras-Português pela Universidade Federal do Espírito Santo. E-mail: cinthiabelonia@gmail.com
} 
católico. Devido à negligência dos pais, Sierva María é criada por Dominga de Adviento, escrava governanta da casa, que a educa segundo os costumes negros. Seu comportamento rotulado como "negro" passa a ser mal interpretado pela sociedade local, principalmente pela Igreja Católica, quando, após sofrer o ataque de um cão em companhia de negros, aguça a suspeição já existente sobre seu comportamento identificado com o ethos dos escravos. À época (século XVIII na América espanhola), estigmatizavam-se as pessoas que contraíam a raiva (Rhabdoviridae). Para a Igreja, que não aceita nenhuma explicação médica, a menina é vítima de uma manifestação demoníaca. A demonologização das práticas culturais de origem negroafricana e ameríndia, reproduzidas pela personagem, constitui, no romance, uma estratégia da Igreja Católica para a perpetuação do poder eclesiástico através da imposição do discurso religioso. Durante o vice-reinado da Colômbia, esse discurso servia à legitimação da inquisição e do sistema escravocrata.

\section{OUTROS DEMÔNIOS: EXCLUSÃO IDENTITÁRIA E DEMONOLOGIZAÇÃO DO ETHOS NEGRO}

Em nossa abordagem referenciamos, como elemento estruturante do discurso de Márquez em Del amor y otros demonios, a demonologização do negro pela empresa colonialista européia, partindo da análise do comportamento de Sierva María de Todos los Ángeles em relação aos senhores brancos e aos escravos negros. Sierva María, protagonista do romance, representa na narrativa o lugar de circulação e cruzamento das representações discursivas etnoculturais do colonizador europeu, do colonizado criollo $^{2}$ afro-descendente e do ameríndio pré-colombiano da América hispânica. O romance se passa no vice-reino espanhol da Colômbia em fins do século XVIII, na época da colonização escravagista e inquisitorial. Na construção da trama narrativa, o embate cultural entre os discursos religioso e científico são representados metaforicamente, como já dissemos, na protagonista do romance. Caracterizada por um

\footnotetext{
${ }^{2} \mathrm{O}$ uso do termo criollo/crioulo neste artigo refere-se a todo aquele que nasceu nas Américas colonizadas pela empresa colonialista européia, agente de formações discursivas híbridas que se afastam da tradição monológica ocidental em busca de uma nova sintaxe que escreva de modo diferente a realidade. As Américas representam, nesse sentido, o lugar da escritura das alteridades constituídas no "novo" continente. O termo crioulo é egresso do latim criare com o sentido de educar. O termo identificava os que nasciam e eram educados nas Américas sem ser originários delas como os ameríndios, passando, entretanto, a indicar, por extensão, homens de todas as raças, animais e plantas que se transportaram para o continente americano a partir de 1492. [...] O Novo Dicionário de Língua Portuguesa de Aurélio Buarque de Holanda Ferreira define crioulo como o indivíduo de raça branca, nascido nas colônias europeias de além-mar, particularmente as das Américas, denominando também de crioulo o dialeto falado por essas pessoas; o negro nascido nas Américas; o dialeto português falado em Cabo Verde e em outras possessões portuguesas da África. [...] Na América hispânica, o termo crioulo não só indica os membros de classes subalternas, nascidos nas Américas, mas também se refere à lógica sincrética do crioulo vernacular como modelo inclusivo com um majoritário aporte de construções sociais. (cf. Magdala França Vianna, Crioulização e Crioulidade, p. 103-5, em Conceitos de Literatura e Cultura, 2005).
} 
comportamento ambíguo, a personagem atua como índice de pesquisa das matrizes culturais que se entrecruzam na narrativa de Gabriel García Márquez. Na passagem que segue, as palavras curanderos e milagro são as chaves de leitura da trama narrativa:

El marqués siguió a tientas el rumbo de la música hasta el dormitorio de la hija. Allí estaba, sentada en la silla del tocador, con la túnica blanca y la cabellera suelta hasta el piso, tocando un ejercicio primario que había aprendido de él. No podía creer que fuera la misma que había dejado al mediodía postrada por la inclemencia de los curanderos, a menos que hubiera ocurrido un milagro. Fue una ilusión instantánea. Sierva María se percató de su llegada, dejó de tocar, y recayó en la aflicción (MÁRQUEZ, 2007, p. 70).

Na citação aponta-se a dúvida que percorre toda a narrativa: o comportamento de Sierva María seria fingimento ou possessão? No texto seguinte sugere-se a hipótese do fingimento:

Sierva María estaba sentada cerca de la puerta principal, entre dos guardianas distraídas, y apenas si probaba bocado. [...] Nadie la miró mientras comía, pero al final varias novicias la rodearon para admirar sus abalorios. Una de ellas trató de quitárselos. Sierva María se encabritó. [...] Rompió cuanto encontró a su paso, saltó por la ventana y desbarató las talanqueras de los establos y las cercas de los corrales. Las abejas se dispersaron y los animales en estampida irrumpieron aullando de pánico hasta en los dormitorios de la clausura. [...] No ocurrió nada desde entonces que no fuera atribuido a los maleficios de Sierva María (MÁRQUEZ, 2007, p. 83).

Ainda que se destaque o comportamento agressivo de Sierva María, atuando como um índice de leitura de manifestações de possessão demoníaca, não há na trama narrativa provas científicas ou imaginárias de que esse seja o estado da menina.

Mesmo antes de Sierva María ser atacada por um cão, sua mãe já identificava nela um comportamento diferente. Sabendo disso, a menina usava de artifícios para assustar a mãe fazendo um barulho estranho seguido de uma ladainha em língua africana: "ella le aumentaba el susto con una retahíla en lengua yoruba" (MÁRQUEZ, 2007, p. 56). Despojada de sua identidade nobre e branca, Sierva María é criada na senzala de acordo com os costumes, cultura e religiosidade dos escravos. Mesmo tendo um quarto na Casa Grande, Sierva María dormia na rede da senzala junto das outras escravas, onde cresceu sob os cuidados da escrava governanta da casa Dominga de Adviento:

La niña, hija de noble y plebeya, tuvo una infancia de expósita. La madre la odió desde que le dio de mamar por la única vez, y se negó a tenerla con ella por temor de matarla. Dominga de Adviento la amamantó, la bautizó en Cristo y la consagró a Olokun, una deidad yoruba de sexo incierto, cuyo rostro se presume tan temible que sólo se deja veer en sueños, y siempre con una máscara. (MÁRQUEZ, 2007, p. 54) 
O ethos negro de Sierva María se representa, pois, nas danças africanas que a personagem aprende desde muito nova e nas línguas mandinga, congo e iorubá, que a menina aprende na senzala antes mesmo do castelhano. Sierva María é dona, também, de um paladar culinário exótico comparado com o europeu, pois comia com os escravos o que era servido na senzala onde eles viviam: “Al almuerzo se comió un plato con las criadillas y los ojos del chivo, guisados en manteca de cerdo y sazonados con especias ardientes” (2007, p. 78). Essa culinária, considerada pelos católicos como exótica, é demonologizada no Convento. Kwame Anthony Appiah, filósofo nascido em Gana, escreve em $\mathrm{Na}$ casa de meu pai: a África na filosofia da cultura, que, na maioria das culturas, os preconceitos alimentares são racializados: "os norteamericanos dizem que os insetos são anti-higiênicos, e o povo achanti, que os gatos devem ter um sabor horrível. No entanto, um inseto cozido não é mais ameaçador do que uma cenoura cozida, e o sabor desagradável da carne de gato, longe de justificar nosso preconceito contra ela, provavelmente decorre desse preconceito" (APPIAH, 2010, p. 40-1).

Sierva María desenvolveu o costume de mentir por vício, principalmente aos brancos, como se só confiasse nos negros. Frantz Fanon escreve, em Pele negra máscaras brancas, que o negro possui dois comportamentos, um com seus semelhantes e outro com o branco. E, de fato, a menina se comporta de forma diferente entre um e outro, igualando-se sempre aos negros. Ao falar a língua mandinga dos negros, Sierva María assume suas práticas culturais, pois a língua é uma das formas de expressão e tradução de uma determinada cultura, de um determinado povo. Como escreve Fanon sobre o negro, na obra Del amor y otros demonios a personagem central suporta, por identificação cultural e afetiva, o peso das consequências dos processos de discriminação étnica dos negros. Ela não reproduz os valores da metrópole, do país colonizador, mas assume os valores da etnia negra com a qual se identifica. Em Pele negra máscaras brancas, Fanon cita Dominique-Octave Mannoni, psicanalista e escritor francês, quando observa que só se percebe a inferioridade da cor da pele entre indivíduos que vivem em minoria em um ambiente de outra cor. Entretanto, nos países colonizados os negros eram maioria, por isso se diz que o processo de demonologização é instituído pelo racismo. Citando Jean-Paul Sartre, Fanon ressalta que o judeu é um homem comum, mas é o antissemita quem cria a condição subalterna do judeu (FANON, 2008, p. 90). Citando também Alan Burns, administrador colonial e governador britânico, Fanon afirma que quem cria o inferiorizado é o racista:

O preconceito de cor nada mais é do que a raiva irracional de uma raça por outra, o desprezo dos povos fortes e ricos por aqueles que eles consideram inferiores, e depois o amargo ressentimento daqueles que foram oprimidos e frequentemente injuriados. Como a cor é sinal exterior mais visível da raça, ela 
tornou-se o critério através do qual os homens são julgados, sem se levar em conta as suas aquisições educativas e sociais. As raças de pele clara terminaram desprezando as raças de pele escura e estas se recusam a continuar aceitando a condição modesta que lhe pretendem impor (BURNS, citado em FANON, 2008, p. 110).

O negro, por ter sido colonizado, escravizado e demonologizado, nada mais é, em sua condição subalterna, que uma criação europeia, uma vez que, antes do contato com o branco, ele não se sentia inferiorizado por nenhuma outra raça. Fanon afirma que o negro é visto pelo branco como a figura do mal, do pecado, como selvagem, animal e, até mesmo Caim ou o diabo. Na Europa, o mal era sempre representado pelo negro, tanto na figura do carrasco quanto na figura de Satã. E acrescenta: “[...] fala-se de trevas quando se é sujo, se é negro - tanto faz se isso se refira à sujeira física ou à sujeira moral" (FANON, 2008, p. 160). Dessa forma, não é estranho o fato de Sierva María ser considerada possessa por apresentar um ethos cultural negro.

\section{O ROSÁRIO DE SÂNDALO E OS COLARES DO CANDOMBLÉ}

Apesar de possuir um nome de batismo católico, Sierva María de Todos los Ángeles se autodenomina María Mandinga, no qual se identificam as marcas da exclusão e discriminação que acompanham a migração interlinguística crioula. Enquanto o nome María identifica em sua carga semântica o discurso monológico da "santificação" branca, Mandinga carrega o discurso da demonologização do negro. O nome referencia em sua carga semântica, as matrizes culturais branca e católica (María) e negro-africana e seus discursos religiosos (Mandinga). Bernarda Cabrera, sua mãe, costumava dizer que a única coisa que a menina tinha de branco era a cor e alternava o nome de Sierva María com o de María Mandinga, inventado pela menina. Tal nome era a forma como Sierva María mostrava se identificar com o universo dos negros, excluindo-se e negando o mundo dos brancos.

A história de Sierva María, como já se sabe, se inicia após ela ter sido atacada por um cão. Além dela, também foram atacados três escravos negros que estavam em sua companhia. Meses depois do ataque, registra-se na narrativa que:

Dos habían desaparecido, sin duda escamoteados por los suyos para tratar de hechizarlos, y un tercero había muerto del mal de rabia en la segunda semana. Había un cuarto que no fue mordido sino apenas salpicado por la baba del mismo perro, y estaba agonizando en el hospital del Amor de Dios. (MÁRQUEZ, 2007, p. 24)

Diferente das outras vítimas, Sierva María estava completamente sã e não apresentava os sintomas da raiva, fazendo sua mãe acreditar que o cão tinha sido contaminado pelo vírus 
rábico, o Rhabdoviridae, após o ataque à filha. A ironia, tão comum nas obras de García Márquez, manifesta-se na maneira como a mãe se refere à fillha. Para Ana María Hernandéz de López (1998), o cão e as consequências do ataque têm um significado importante no romance, pois o que motiva a narrativa é o ataque do cão como leitmotif, repetindo-se em todos os cinco capítulos contribuindo para maior veracidade do ocorrido, como se o narrador, a todo o momento, procurasse chamar a atenção do leitor para a ferida na perna de Sierva María, como coisa real, desconsiderando, dessa forma, a possível possessão.

Embora a mãe considerasse a menina como uma presença fantasmagórica assustadora, dizia-se "dispuesta a hacer la farsa de las lágrimas y a guardar un luto de madre adolorida por preservar su honra, con la condición de que la muerte de la niña fuera por una causa digna" (MÁRQUEZ, 2007, p. 25). Sendo a mãe filha de índio e o pai, crioulo, o casal não poderia sofrer a humilhação de ter uma filha contaminada pelo vírus da raiva, revelando o estigma de uma posição social híbrida, ou como se lê em O Realismo Maravilhoso de Irlemar Chiampi:

Toda a projeção eufórica do mestiço passa pela reabilitação dos seus componentes raciais: se a mistura de sangues se torna aceitável para o branco, é porque o negro e o índio adquirem status de humanidade e as suas culturas começam a ser repensadas dentro dos novos enfoques da História. (CHIAMPI, 1980, p. 116)

Sierva María era branca, mas tinha hábitos e valores negros, por isso sua mãe, que era mestiça, não adquiriu, através dela, o status de humanidade. O comportamento de Sierva María, identificado com o ethos dos escravos e rotulado como "negro", passa a ser mal interpretado pela sociedade local, principalmente pela Igreja Católica, aguçando a suspeição já existente. À época, os sintomas da raiva (Rhabdoviridae) eram rotulados de manifestação demoníaca e as pessoas que contraíam a doença eram estigmatizadas pelo discurso religioso que não reconhecia como valor o saber veiculado pelo discurso científico. A demonologização das práticas culturais de origem negro-africana reproduzidas pela personagem revela-se, na metáfora literária, como estratégia discursiva da Igreja Católica para a perpetuação do poder eclesiástico.

A identidade da menina é a de um ser caracterizado pela hibridação cultural, pois possui características físicas da raça branca, é da classe aristocrática, mas não se sente "em casa", segundo Palencia-Roth, no espaço sociocultural e religioso dos brancos. Seu lar ficava no espaço destinado aos escravos, a senzala, onde Sierva María adquiriu sua identidade cultural, compartilhando com eles suas línguas, seus costumes e religião. 
Adriana Albet Dias (2004), em sua dissertação, “A malandragem da mandinga: o cotidiano dos capoeiras em Salvador na República Velha (1910-1925)"3, escreve que a mandinga é uma característica essencial da capoeira, sendo usada (a palavra mandinga) como sinônimo de capoeira. É considerada uma arma de defesa e ataque dos praticantes, sendo observada nas músicas cantadas nas rodas, no molejo do corpo do jogador e nos golpes executados. A mandinga, como fingimento e malícia na capoeira, caracteriza o comportamento de Sierva María.

A malandragem estava presente na vida dos capoeiristas no início do século $\mathrm{XX}$, no jogo de pernas para o ataque e a defesa e na esperteza dentro e fora da roda de capoeira. Era parte da cultura de rua, do modo de ser das estratégias de sobrevivência de homens que viviam entre a ordem e a desordem, perseguidos por policiais, quase sempre enfrentando-os ou se esquivando deles, muitas vezes desde criança. A malandragem une-se à desconfiança, comportamento típico de quem ataca de surpresa. Atualmente a mandinga é conhecida na capoeira como uma forma de jogar, tendo como objetivo enganar o adversário com astúcia. No entanto, ela ainda está associada à proteção mágica ao corpo do capoeira, como o uso de um patuá. No passado essa era a principal arma do capoeira, sobrepondo-se até mesmo à força física.

Para Michael Palencia-Roth (S/D), o narrador contrapõe a personagem Sierva María de Todos los Ángeles ao grupo de personagens que discriminam a cultura negra apresentada pela menina, denunciando a intolerância e o preconceito. É a partir da intervenção que a Igreja Católica faz na vida da personagem que os leitores podem perceber o repúdio do escritor representado na figura do narrador pelas injustiças representadas no romance. Palencia-Roth escreve ainda que, para Gabriel García Márquez, a hierarquia da Igreja Católica e a aristocracia se consideravam superiores às classes marginalizadas da Colômbia colonizada, como os escravos e os judeus (religião do médico Abrenuncio), em relação à raça, classe social, intelecto e espírito. O discurso crítico de Márquez sobre a demonologização do negro exercita-se assim em todo o romance conforme expõe Palencia-Roth:

Es interesante la representación garcíamarquiana sobre su interpretación de los hechos en tomo a las actuaciones de Sierva María, que hacen los miembros de la iglesia católica. Estos últimos al imitar el modelo de la ideología de la inquisición europea asumen la posesión de la verdad y por ende la posición de superioridad sobre cualquier otro conocimiento religioso y metafísico. Por consecuente, los eclesiásticos asumen la realidad exterior de acuerdo con su propia lente, y rechazan cualquier diferencia o acto que no esté dentro del campo de su visión ideológica, sin detenerse a pensar en que pueden existir equivocaciones en cuanto al veredicto popular de que Sierva María está endemoniada. Basta con que el nombre del enemigo capital se mencione en

\footnotetext{
${ }^{3}$ Dissertação de Mestrado em História, Universidade Federal da Bahia, 2004.
} 
relación con los síntomas de la rabia, para no dudar que las actuaciones de furia y las palabras extrañas que profiere la niña, que no son otras que las de la lengua yoruba, son la obra del demonio. Así mismo, las actuaciones positivas de la niña las juzgan con sectarismo. (PALENCIA-ROTH, S/D)

Sierva María de Todos los Ángeles, ao ser criada por Dominga de Adviento, é consagrada a Cristo e a Olocum, divindade de sexo incerto e que só se permite ver em sonhos, mesmo assim, sempre com uma máscara. Em alguns lugares do mundo, essa divindade é cultuada como homem e em outros é cultuada como mulher. Para o estudo dessa referência cultural, recorremos à obra de Lydia Cabrera, pesquisadora das religiões cubanas de raízes negro-africanas, Iemanjá \& Oxum. Na obra de Cabrera, referencia-se que a orixá Iemanjá, cultuada como mulher no Brasil, é a divindade Olocum:

\begin{abstract}
Quando Olodumaré, Deus Todo-Poderoso, andava por este planeta, nele existia apenas fogo (e ele imitava o fragor de um incêndio), fogo e rochas ardendo. [...] Então, Olodumaré decidiu que a Terra existisse, com suas montanhas, seus vales e savanas. $\mathrm{O}$ vapor cadente das chamas que se acumulara no espaço foi convertido por Olodumaré em nuvens. Nas partes do degrau onde o fogo foi mais violento, ficaram, quando ele se apagou, uns buracos enormes e muito fundos. No mais profundo deles, nasceu Olocum, o oceano. Olocum, a Iemanjá mais velha - Iemanjá masculina -, raiz, Orisón das demais, pois Iemanjá é uma e sete ao mesmo tempo. (CABRERA, 2004, p. 30)
\end{abstract}

Conforme Lydia Cabrera nos apresenta Olocum em seu livro, constatamos que muito da personalidade de Sierva María se assemelha à da divindade iorubá. Isso justifica a consagração da protagonista a Olocum, que se caracteriza como se lê em Cabrera:

\begin{abstract}
Olocum "é metade homem, metade peixe" e vive no fundo do oceano, junto a uma gigantesca serpente marinha que, segundo dizem, assoma a cabeça na lua nova. [...] Olocum é tão poderoso e terrível que, embora ele seja louvado e honrado nas festas de santo, não possui seus filhos, "não monta", pois eles sucumbiriam, não poderiam resistir à sua força. [...] Não se vê Olocum. Uma velhinha que morreu centenária me confessava que o vira em sonhos duas vezes durante sua longa vida, pois somente em sonhos ele pode ser contemplado. [...] Essa poderosa divindade é representada por meio de uma máscara sagrada que se guardava com muito mistério. [...] Embora Olocum, o oceano, "seja homem" [...] comumente também se ouve falar dele como uma divindade feminina e belíssima, procedente de Oió [...]. "Olocum é macho e fêmea", andrógino $(O k o b o)$. Citando Omí Dina: "De sexo anfíbio". [...] Fundamentalmente, é macho. Assim se diz $O$ Mar. E é fêmea, $A$ Mar, em outros aspectos. Por isso, quando se entra no mar, deve-se dizer: "Papai, Mamãe, Iemanjá-Olocum". (CABRERA, 2004, p. 35-6)
\end{abstract}

A pesquisadora lembra ainda que existe apenas uma Iemanjá, e esta possui sete caminhos, chamados também de avatares. O ataque do cão se explica no imaginário afro-cubano onde se reconhecem as semelhanças de Olocum/Iemanjá com Sierva María: 
Um dia, o cachorro de Ogum, seguindo seu rastro (de Iemanjá) pela mata, encontrou-a nos braços de seu amante Agróniga (Obaluaiê). O cachorro correu em busca de seu dono, que esse dia não saíra de casa e estava na tenda de ferreiro. Levou-o até o lugar onde Iemanjá e Agróniga marcavam encontro e os surpreendeu. O cachorro se lançou furioso sobre ela e a mordeu. Este é o motivo pelo qual os cachorros inspiram terror a Iemanjá. (CABRERA, 2004, p. $52-3)$

Em Del amor y otros demonios, o narrador menciona que Sierva María usava 16 colares de orixás: "Poco a poco, las esclavas le habían ido colgando los collares de distintos dioses, hasta el número de dieciséis" (MÁRQUEZ, 2007, p. 54). Mais adiante, em uma sequência narrativa na qual se inclui um pároco do bairro negro, Tomás de Aquino de Narváez, antigo fiscal do Santo Ofício em Sevilha, que devolve a Sierva Maria os colares do candomblé que lhe haviam sido proibidos, a menina os identifica em línguas africanas:

A medida que se los colgaba en el cuello a Sierva María los iba enumerando y difiniendo en lenguas africanas: el rojo y blanco del amor y sangre de Changó, el rojo y negro de la vida y la muerte de Elegguá, las siete cuentas de agua y azul pálido de Yemanjá. Él se passeaba con tacto sutil del yoruba al congo y del congo al mandinga, y ella lo seguía con gracia e fluidez. (MÁRQUEZ, 2007, p. 153)

Em Iemanjá \& Oxum esse número é explicado: “à descida dos santos que formaram o mundo, em número de dezesseis, com Ogum à frente, abrindo caminho no matagal" (CABRERA, 2004, p. 32). Sierva María usava um colar para cada entidade. Sobre o uso dos colares, escreve Cabrera: "Eles atuam como nossos escapulários e todo isayu ou praticante da Regla de Ocha deve usar sempre o ileke de seu orixá tutelar como distintivo e proteção, para poder dizer: Elemí emí ko chocho (Deus meu, proteja-me, não me deixe só.)" (CABRERA, 2004, p. 123). Isso explica o comportamento agressivo de Sierva María sempre que tentam tirar os seus colares. Tal feito passa a ocorrer somente no Convento. Sobre a ambiguidade de Sierva María, citamos ainda Cabrera: “Olocum também é representado por uma boneca com duas caras e essa imagem só a vimos feita de chumbo, acompanhada de uma estrela do mesmo metal” (2004, p. 264). Assim como a entidade, a personagem é ambígua, possuindo, por isso, um comportamento dúbio, que não é fácil distinguir.

Os colares de Sierva María foram colocados nela junto do escapulário de batismo. Para Ana María Hernández de López (1998), os colares e o escapulário simbolizam as superstições e as crenças sobrenaturais que coexistiram em cidades coloniais. No que diz respeito às práticas culturais dos indígenas e escravos, apesar da dor pela perda de suas terras, esses povos resistiram 
à perda de sua fé, como se mostra na narrativa de Márquez na representação dos signos do catolicismo e dos emblemas das outras religiões nativas ou transplantadas. López assinala que, para García Márquez, os ritos e práticas africanas eram menos cruéis que os métodos utilizados pela Inquisição, uma vez que os negros sacrificavam animais a seus deuses, já o Santo Ofício queimava pessoas inocentes em verdadeiros espetáculos públicos.

Uma das escravas do Convento de Santa Clara, ao ver Sierva María no pátio, reconhece os colares de candomblé. Identificando-se com a menina, a escrava leva-a até a cozinha. Ao perguntarem o que aconteceu com seu tornozelo, ela responde que a cicatriz é de uma ferida feita por sua mãe com uma faca. Como costumava mentir por vício, ela usa desse estratagema para esconder a verdade sobre o tornozelo ferido pelo cão. Quando perguntaram seu nome, disse chamar-se María Mandinga. Na cozinha, junto das escravas, Sierva María recupera seu ethos negro:

Ayudó a degollar un chivo que se resistía a morir. Le sacó los ojos y le cortó las criadillas, que eran las partes que más le gustaban. Jugó al diábolo con los adultos en la cocina y con los niños del patio, y les ganó a todos. Cantó en yoruba, en congo y en mandinga, y aun los que no entendían la escucharon absortos. Al almuerzo se comió un plato con las criadillas y los ojos del chivo, guisados en manteca de cerdo y sazonados con especias ardientes. (MÁRQUEZ, 2007, p. 78)

A abadessa do Convento, Josefa Miranda, ao ouvir o canto da menina, fica deslumbrada com sua voz, no entanto não sabe ainda de quem se trata. Ao ser informada de que o canto era produzido pela "possessa" que ela aguardava, a abadessa foi para a cozinha erguendo o crucifixo que trazia ao pescoço:

La abadesa acababa de hacer la siesta cuando oyó una canción de una sola voz que llenó el ámbito del Convento. Tiró del cordón que pendía al lado de su cama, y una novicia apareció al instante en la penumbra del cuarto. La abadesa le preguntó quién cantaba con tanto dominio. "La niña", dijo la novicia. Todavía adormilada, la abadesa murmuró: "Que voz tan bella". Y enseguida dio un salto: "¡Cuál niña!” / "No sé”, le dijo la novicia. "Una que tiene el traspatio alborotado desde esta mañana". / ¡Santísimo Sacramento!”, gritó la abadesa. Saltó de la cama. Atravesó el Convento a las voladas, y llegó hasta el patio de servicio guiándose por la voz. Sierva María cantaba sentada en un banquillo, con la cabellera extendida por los suelos, en medio de la servidumbre hechizada. Tan pronto como vio a la abadesa dejó de cantar. La abadesa levantó el crucifijo que llevaba colgado del cuello. "Ave María purísima", dijo. / "Sin pecado concebida", dijeron todos. La abadesa blandió el crucifijo como un arma de guerra contra Sierva María. "Vade retro", gritó. Los criados retrocedieron y dejaron a la niña sola en su espacio, con la vista fija y en guardia. "Engendro de Satanás", gritó la abadesa. "Te has hecho invisible para confundirnos". (MÁRQUEZ, 2007, p. 80-1) 
Como haviam dito a ela que a menina estava possuída pelo demônio, tudo o que acontece daí em diante no Convento será atribuído aos demônios presentes no corpo de Sierva María. Não só a abadessa, mas todas as Irmãs Clarissas do Convento lhe atribuem todos os acontecimentos, considerados por elas como anormais. Sierva María se tornava muito agressiva sempre que tentavam retirar algum dos seus colares de candomblé, por isso era considerada pelas freiras como dona de uma força de outro mundo. Entretanto, as Clarissas, noviças do Convento de Santa Clara, movidas pelo tédio, pareciam ter mais curiosidade do que medo:

Pero los terrores de las clarissas eran contradictorios, pues a pesar de los aspavientos de la abadesa y de los pavores de cada quién, la celda de Sierva María se convirtió en el centro de la curiosidad de todas. [...] Una niña endemoniada dentro del Convento tenía la fascinación de una aventura novedosa (MÁRQUEZ, 2007, p. 84).

Sobre a criação de Sierva María, é importante dizer que a senzala constituía o local onde a menina se sentia livre para manifestar seu comportamento sem sofrer nenhum tipo de discriminação. A exclusão geográfica, demarcada pela fronteira que separava a senzala da Casa Grande, proporcionava a Sierva María um sentimento de proteção em relação à sociedade escravocrata, na qual nenhum escravo poderia experimentar a mesma liberdade que ela. A menina tinha liberdade para transitar no mundo dos brancos por ser essa a sua cor, além de transitar também no mundo dos negros por se identificar culturalmente com os mesmos, e esse livre trânsito não era permitido aos escravos. Graças a essa criação "negra", a marquesinha branca cresceu diferente dos seus, mas também não tão igual aos negros. Afinal, por mais que se parecesse com eles devido aos costumes que mantinha, ela não era uma deles, mas era capaz de atravessar a fronteira que há entre senhores e escravos. Tal característica era típica dos negros e dos colonizados para sobreviverem em um mundo de repressão. Sobre isso, o pensador indobritânico Homi Bhabha, em O local da cultura, escreve que:

A invisibilidade apaga a autopresença daquele "Eu" em termos do qual funcionam os conceitos tradicionais de agência política e domínio narrativo. O que toma (o) lugar, no sentido do suplemento derridiano, é o mau olho desencarnado, a instância subalterna que executa a sua vingança circulando sem ser visto. Ele atravessa as fronteiras entre senhor e escravo; ele abre um espaço interalar entre os dois locais do poema, o Hemisfério Sul da escravidão e o Hemisfério Norte da diáspora e da migração, que então se tornam estranhamente duplicados no centenário fantasmático do inconsciente político. Esta duplicação resiste ao tradicional elo causal que explica o racismo metropolitano contemporâneo como resultado dos preconceitos históricos das nações imperialistas. O que ela de fato sugere é uma nova compreensão de ambas as formas de racismo, baseada em suas estruturas simbólica e espacial 
comuns - a estrutura maniqueísta de Fanon - articuladas dentro de diferentes relações temporais, culturais e de poder. (BHABHA, 2007, p. 91)

Por isso a personagem é híbrida, não podendo ser classificada em uma única identidade. Como hispano-americana, produto da colonização, ela possui características do pluriculturalismo que identifica muitos povos colonizados. Stuart Hall, pensador jamaicano fundador do centro de Estudos Culturais da Universidade de Birmingham (Inglaterra), afirma que:

A distinção de nossa cultura é manifestadamente o resultado do maior entrelaçamento e fusão, na fornalha da sociedade colonial, de diferentes elementos culturais africanos, asiáticos e europeus. [...] Esse resultado híbrido não pode mais ser facilmente desagregado em seus elementos "autênticos" de origem. (HALL, 2011, p. 31)

Quem fazia a ligação entre os dois mundos onde a menina vivia era Dominga de Adviento, a escrava governanta da casa que criara Sierva María: "Se había hecho católica sin renunciar a su fe yoruba, y practicaba ambas a la vez, sin orden ni concierto" (MÁRQUEZ, 2007, p. 20). Foi nesse contexto cultural híbrido que Sierva María cresceu. Refletindo sobre o contexto sócio-político-cultural das Américas pós-coloniais, Stuart Hall escreve sobre o hibridismo religioso que presenciou tanto no Haiti como na Jamaica, onde, segundo o teórico, pode-se sentir a "África” devido ao sincretismo religioso, à incorporação dos santos católicos aos deuses africanos no vodu haitiano. A leitura de Da diáspora: identidades e mediações culturais (2011) nos remete a um possível diálogo polissêmico - considerando-se a reflexão de Mikhail Bakhtin sobre a existência de um dialogismo ${ }^{4}$ entre séries discursivas conceituais e ficcionais entre a personagem Dominga de Adviento e André Pierre, pintor francês contemporâneo, que, segundo Hall, “[...] fazia uma prece a ambos os deuses, cristão e vodu, antes de iniciar seu trabalho" (HALL, 2011, p. 32). Hall assinala que esse hibridismo está presente em toda a América Latina na construção triádica "pecado-contrição-absolvição", lembrando-se que o baile da terça-feira de carnaval vem seguido da missa de quarta-feira de cinzas. O teórico jamaicano nos diz ainda que, em todo lugar, há a différance, tal como a concebe Derrida em A escritura e a diferença (1971), uma vez que a diferença é essencial ao significado, e este é inerente à cultura. Hall assinala ainda que o termo "hibridismo não se refere a indivíduos híbridos. [...] Trata-se de

\footnotetext{
${ }^{4}$ Segundo Bakhtin, todas as séries, literárias e não-literárias, derivam do que ele chama de "poderosas e profundas correntes da cultura". Para ele, "a literatura não pode ser compreendida fora do contexto global da cultura de uma determinada época”. (BAKHTIN, Mikhail. Marxismo e filosofia da linguagem. São Paulo: Hucitec, 1995). O dialogismo bakhtiniano aplica-se tanto ao discurso cotidiano como à tradição literária e artística e diz respeito a todas as séries que atuam no texto, seja ele verbal, não-verbal, erudito ou popular.
} 
um processo de tradução cultural, agonístico uma vez que nunca se completa, mas permanece em sua indecidibilidade" 5 (2003, p. 74), sua incompletude.

\section{CONCLUSÃO}

Para Guilhermo Tedio, no texto "Del amor y otros demonios o las erosiones del discurso inquisitorial", o demônio está presente no romance não só na interpretação que os brancos têm dos negros, mas também entre os agentes da autoridade: a abadessa, o bispo, o marquês e sua esposa. A abadessa, segundo Cayetano Delaura, estava possuída por demônios de rancor, intolerância e imbecilidade. O narrador diz que o bispo estava corroído por uma asma maligna que fazia desconfiar de sua fé. O marquês de Casalduero, pai de Sierva María, sente que está apodrecendo. E o mesmo é dito de sua esposa, que expelia flatulências letais. O narrador exercita em sua narrativa uma linguagem rica de referências ao demônio a partir de animais tomados pela tradição como diabólicos, tais como: galo, bode, porco, iguana, aranha e serpente.

Palencia-Roth chama a atenção para o discurso do narrador, que aponta os equívocos cometidos pelo Santo Ofício que sacrificava em fogueiras muitos inocentes por serem contrários aos princípios católicos. Muitas negras, por exemplo, foram condenadas por bruxaria. A acusação de Sierva María de possessão a associa com a cultura negra. Em seguida, PalenciaRoth faz uma interpretação dos possíveis "outros demônios" referenciados no título do romance:

La verdad que porta este discurso novelesco es, entonces, la de que los verdaderos demonios, contra los cuales pelean los simpatizantes de la inquisición, son los mismos inquisidores con sus juicios dogmáticos, autoritarios, a la ligera y con sus procedimientos de verdugos cuando hacen exorcismos. Por otra parte, el narrador expresa que el obispo es el demonio a los ojos de Sierva María. [...] Por consecuente, los lectores y lectoras podemos deducir que los demonios a que hace referencia el título de la obra son los miembros de la Iglesia católica en su tarea de inquisidores. (PALENCIAROTH, N/D)

Palencia-Roth diz que, na Cartagena colonial do século XVIII, a possessão representada na personagem de Sierva María, se desenvolvia dentro das normas do Santo Ofício, que se estabeleceu em Cartagena em 1610, permanecendo até o início do século XIX. O Santo Ofício era um Conselho de controle social, perfeita metáfora da escravidão que saturava a vida dos cartageneses na época colonial. Para Guilhermo Tedio, tal Conselho ajudou também a manter na América o comércio negreiro que favorecia os senhores feudais.

\footnotetext{
${ }^{5}$ A indecidibilidade, conceito desenvolvido por Derrida, refere-se à incompletude ou a interminabilidade do signo, como um labirinto cuja saída tanto pode ser uma decifração como uma irresolução.
} 
A causa da demonologização do negro é o racismo que eles sofriam por parte dos espanhóis e crioulos. Segundo Maarten Steenmeijer em "Racismo utópico en Del amor y otros demonios", a etnia e a cultura africana no romance de García Márquez têm vários papéis:

Un examen somero muestra que los negros tienen el rol tópico de esclavos, es decir, de seres que la comunidad dominante considera como infrahumanos y que la historia oficial niega. Son, igualmente, una presencia inquietante o incluso una amenaza para la elite criolla, por tener otros rituales, otros idiomas, otros códigos y, demás, por irradiar la vitalidad de la mala hierba. (STEENMEIJER, 2002, s/p)

Para ele, foram o fanatismo e a intolerância os culpados pela morte prematura de Sierva María de todos los Ángeles.

Palencia-Roth diz que a natural e sensual maneira de ser da cultura africana serve como contraponto à repressiva e fria cultura branca, espanhola e católica, que interpreta como manias do demônio muitas paixões normais ao ser humano. Mesmo sendo crioula e mestiça, Sierva María tem a espiritualidade africana. Nela se mesclam simbolicamente o sangue das três culturas mais importantes da Colômbia, mas a base de sua salvação, de sua beatificação simbólica e estética é principalmente africana. Segundo Palencia-Roth, García Márquez reconhece e celebra o fato de que dentro de todo colombiano do Caribe, atrás da máscara espanhola e católica, bate o coração de um ser africano. Entretanto, para Steenmeijer, celebrar não é o termo mais adequado, visto que os negros têm voz apenas no romance, pois o discurso é dominado por um narrador que simpatiza com eles, mas não vive com eles.

\section{REFERÊNCIAS}

APIAH, K. A. Na casa de meu pai: a África na filosofia da cultura. Tradução de Vera Ribeiro. Revisão da tradução por Fernando Rosa Ribeiro. Rio de Janeiro: Contraponto, 1997.

BHABHA, H. K. O local da cultura. Tradução de Miryam Ávila, Eliana Lourenço de Lima Reis, Gláucia Renate Gongalves. Belo Horizonte: EDUFMG, 2007.

CABRERA, L. Iemanjá \& Oxum: Iniciações, Ialorixás e Olorixás. Tradução de Carlos Eugênio Marcondes de Moura. São Paulo: EDUSP, 2004.

CHIAMPI, I. O Realismo Maravilhoso. Forma e Ideologia no Romance Hispano-americano. São Paulo: Perspectiva, 1980.

DERRIDA, J. A Escritura e a diferença. / L'écriture et la différence. / Tradução de María Beatriz Marques Nizza da Silva. São Paulo: Perspectiva, 1971. (Debates, 49) 
DIAS, A. A. A malandragem da mandinga: o cotidiano dos capoeiras em Salvador na República Velha (1910-1925). Dissertação (Mestrado em História), Faculdade de Filosofia e Ciências Humanas, Universidade Federal da Bahia, Salvador, 2004.

Disponível em: http://www.ffch.ufba.br/spip.php?article240. Acesso em: 10 de outubro de 2013.

FANON, F. Pele negra máscaras brancas. Tradução de Renato da Silveira. Salvador: EDUFBA, 2008.

HALL, S. Da diáspora: identidades e mediações culturais. Belo Horizonte: EDUFMG; Brasília: Representação da UNESCO, 2003.

A identidade cultural na pós-modernidade. Tradução de Tomaz Tadeu da Silva, Guaracira Lopes Louro. 11 $1^{\mathrm{a}}$ ed., $1^{\mathrm{a}}$ reimp. Rio de Janeiro: DP\&A, 2011.

LÓPEZ, A. M. H. Del amor y otros demonios: relectura de la novela. In: Actas del XII Congreso de la Asociación Internacional de Hispanistas, 21-26 de agosto de 1995, Birmingham, Vol. 6, 1998, págs. 291-297.

MÁRQUEZ, G. G. Del amor y otros demonios. Buenos Aires: De bolsillo, 2007.

PALENCIA-ROTH, M. "Del amor y otros demonios: tragedia inquisitorial, beatificación a africana". Disponível em: http://javeriana.edu.co. Acesso em: 22 abrl. 2013.

STEENMEIJER, M. "Racismo utópico en Del amor y otros demonios de Gabriel García Márquez". In: Espéculo. Revista de estúdios literarios. Universidade Complutense de Madrid, 2002. Disponível em: http://www.ucm.es. Acesso em: 22 abrl. 2013.

TEDIO, G. "Del amor y otros demonios o las erosiones del discurso inquisitorial". In: Espéculo. Revista de estúdios literarios. Universidade Complutense de Madrid, 2005. Disponível em: http://www.ucm.es. Acesso em: 22 abrl. 2013.

Recebido em: 19/02/2018

Aprovado em: 01/04/2018

Publicado em: 01/07/2018 